\title{
FAKTOR YANG BERHUBUNGAN DENGAN KEJADIAN PERSALINAN PREMATUR DI RSUD DR SOETOMO
}

\section{FACTORS RELATED TO THE EVENT OF PREMATURE LABOR IN RSUD DR SOETOMO}

\author{
Noza Loviana ${ }^{1}$, Ninik Darsini ${ }^{2}$, Aditiawarman $^{2}$
}

\author{
1. Program Studi Pendidikan Bidan, Fakultas Kedokteran, Universitas \\ Airlangga \\ 2. Fakultas Kedokteran, Universitas Airlangga \\ Alamat korespondensi: \\ Gg. Sekolahan RT 3 RW 3. Mulyaharja, Bogor Selatan, Bogor, Indonesia \\ Email: noza.loviana-2017@fk.unair.ac.id
}

\begin{abstract}
Abstrak
Latar Belakang: Secara global, persalinan preterm menjadi penyebab utama kematian neonatus usia dini 0-7 hari pertama kehidupan dengan menimbulkan dampak morbiditas yang tinggi juga. Indonesia menempati urutan negara ke 5 estimasi persalinan preterm tertinggi di dunia. Beberapa faktor yang dapat berpengaruh terhadap persalinan preterm yaitu idiopatik, iatrogenik, sosiodemografi, maternal dan genetik. Penelitian ini bertujuan untuk melihat hubungan antara usia ibu, pendidikan ibu, pekerjaan ibu dan riwayat persalinan preterm terhadap kejadian persalinan prterm di RSUD Dr. Soetomo Surabaya. Metode: Metode penelitian ini adalah analitik observasional dengan rancang bangun case control. Jumlah populasi sebanyak 1311 orang pada periode 1 Januari - 31 Desember 2018. Sampel dibagi dalam dua kelompok yaitu kelompok kasus (ibu yang bersalin preterm) dan kelompok kontrol (ibu yang bersalin tidak preterm) sebanyak masing-masing kelompok 137 orang yang disesuaikan dengan kriteria inklusi dan eksklusi dan berdasarkan teknik pengambilan sampel yaitu simpel random sampling. Variabel independen terdiri dari usia ibu, pendidikan, pekerjaan dan riwayat persalinan preterm sedangkan variabel dependen adalah persalinan preterm. Analisis data bivariat menggunankan uji Chi-Square test dengan taraf signifikansi $\alpha=0,05(95 \%$ CI). Hasil: Hasil uji Chi-Square menunjukkan bahwa tidak ada hubungan bermakna antara usia ibu bersalin (nilai $\mathrm{p}=0,259$ ), pendidikan (nilai $\mathrm{p}=1$ ), pekerjaan (nilai $\mathrm{p}=$ 0,225 ) dan riwayat persalinan preterm (nilai $\mathrm{p}=0,191$ ) dengan kejadian persalinan preterm. Kesimpulan: Faktor risiko seperti usa ibu bersalin, pendidikan ibu, pekerjaan ibu dan riwayat persalinan preterm tidak memiliki hubungan terhadap kejadian persalinan preterm.
\end{abstract}

Kata kunci: persalinan prematur, usia, pendidikan, pekerjaan, riwayat persalinan preterm

\begin{abstract}
Abtract
Background: Globally, preterm labor is the main cause of neonatal mortality in the first 0-7 days of life with a high impact of morbidity. Indonesia ranks 5 th in the highest estimate of preterm labor in the world. Several factors that can influence preterm labor are idiopathic, iatrogenic, sociodemographic, maternal and genetic. This study aims to look at the relationship between maternal age, maternal education, maternal occupation and a history of preterm labor against the incidence of prenatal labor in RSUD Dr. Soetomo Surabaya. Method : The method of this study is observational analytic with a case-control design. The total population is 1311 people in the period January 1 - December 31, 2018. Samples were divided into two groups, namely the case group (preterm maternity) and the control group (mothers who were not preterm) as many as 137 groups each according to the inclusion criteria and exclusion and based on sampling techniques, namely simple random sampling. Independent variables consisted of maternal age, education, occupation and a history of preterm labor while the dependent variable was preterm labor. Bivariate data analysis used the Chi-Square test with a significance level of $\alpha=0.05(95 \%$ CI). Results : The Chie-ISSN 2656-7806 @ 2019
\end{abstract}


Square test results showed that there was no significant relationship between maternal age ( $p=$ $0.259)$, education $(p=1)$, employment $(p=0.225)$ and preterm labor history $(p=0.191)$ with the incidence of preterm labor. Conclusion: Risk factors such as maternal age, maternal education, maternal occupation and a history of preterm labor have no relationship to the incidence of preterm labor.

Keywords: preterm labor, age, education, occupation, preterm labor history

\section{PENDAHULUAN}

Persalinan preterm adalah persalinan yang terjadi pada usia kehamilan $<37$ minggu atau 259 hari sejak hari pertama haid terakhir (Blencowe et al., 2012). Persalinan preterm merupakan masalah penting karena menjadi penyebab kematian utama pada neonatus usia dini yaitu usia 0-7 hari pertama kehidupan (WHO, 2018). Menurut WHO (2018) pada tahun 2017 tercatat angka prematuritas di dunia sebesar 6,5 per 100 kelahiran hidup. Angka ini tidak jauh berbeda pada Indonesia (2018) yaitu sebsar 4,8 per 1000 kelahiran hidup (WHO, 2108) dan Indonesia menjadi negara terbesar 5 dengan jumlah estimasi persalinan preterm tertinggi di dunia (Blencowe et al., 2012). Berdasarkan hasil penelitian sebelumnya di RSUD Dr. Soetomo didapatkan bahwa ada 7,8\% kematian neonatus dini dan $55,4 \%$ nya terjadi pada bayi prematur (Djajakusli, Harianto dan Etika, 2017).

Persalinan preterm ini mengacu pada kelahiran bayi prematur. Kesulitan utama pada bayi prematur ialah perawatan dikarenakan belum sempurnaya sistem tubuh serta organ lainnya untuk berfungsi sendiri. Hal ini dapat menimbulkan komplikasi pada bayi prematur seperti respiratory distress syndrome (RDS), perdarahan intraventrikular, displasia bronkopulmoner (BPD), patem duktus arteriosus (PDA), necrotizing entero cilitis (NEC), sepsis, apnea, dan retinopathy of prematurity (ROP) (Lissauer \& Farnaroff, 2013). Komplikasi bayi prematur ini selanjutnya dapat meningkatkan morbiditas dan mortalitas neonatus sehingga semakin muda usia kehamilan, maka semakin besar pula morbiditas dan mortalitasnya (Mochtar, 2010). Terdapat beberapa faktor yang berpengaruh terhadap persalinan preterm yaitu idiopatik dimana 50\% penyebabnya tidak diketahui secara pasti, iatrogenik dikarenakan keadaan medis dalam kehamilan, sosio-demografi, faktor maternal dan faktor genetik (Krisnadi et al, 2009).

Faktor demografik seperti usia ibu menurut penelitian Syarif, Santoso dan Widyasih (2017) memiliki hubungan dengan kejadian persalinan preterm dengan 
usia risiko yaitu dibawah 20 tahun dan diatas 35 tahun serta menurut teori Soewarto (2010) usia terbaik untuk melahirkan adalah usia 20-35 tahun. Pendidikan ibu menurut penelitian di RSUP Prof. Dr. R. D. Kandou Manado menyebutkan bahwa pendidikan sangat berpengaruh terhadap pengetahuan ibu akan pentingnya pemeliharaan kandungan yang baik selama kehamilan (Ondang, Suparman dan Tendean, 2016). Faktor sosial seperti pekerjaan ibu menurut teori dapat meningkatkan kejadian persalinan preterm melalui kelelahan fisik maupun stres akibat pekerjaan (Krisnadi, Effendi dan Pribadi, 2009). Faktor maternal seperti riwayat persalinan preterm berdasarkan penelitian yang dilakukan di Scotlandia menunjukkan bahwa riwayat persalinan preterm sebelumnya akan meningkatkan resiko persalinan preterm selanjutnya 3 kali lipat (Fadlun dan Feryanto, 2011).

Tujuan dari penelitian ini adalah untuk melihat hubungan antara usia ibu, pendidikan ibu, pekerjaan ibu dan riwayat persalinan preterm terhadap kejadian persalinan prterm di RSUD Dr. Soetomo Surabaya. Hipotesis penelitian yaitu "Ada hubungan antara usia ibu dengan kejadian persalinan preterm", “Ada hubungan antara pendidikan ibu dengan kejadian persalinan preterm”, “Ada hubungan antara pekerjaan ibu dengan kejadian persalinan preterm", dan "Ada hubungan antara riwayat persalinan preterm dengan kejadian persalinan preterm”.

\section{METODE}

Jenis penelitian ini menggunakan penelitian analitik observasional dengan rancang bangun case control.Populasi pada penelitian ini dibagi dalam populasi kasus yaitu ibu yang bersalin secara prematur dan populasi kontrol yaitu bersalin tidak preterm di RSUD Dr. Soetomo Surabaya pada periode 1 Januari 2018- 31 Desember 2018 dengan jumlah kedua populasi yaitu 1311 orang. Sampel dibagi dalam dua kelompok yaitu sampel kasus adalah ibu yang bersalin preterm dan kelompok kontrol adalah ibu yang bersalin tidak preterm. Sampel dipilih berdasarkan kriteria inklusi dan kriteria eksklusi. Kriteria inklusi yaitu metode persalinan secara spontan, sectio cesarea maupun dengan bantuan alat (sampel kasus dan kontrol), ibu yang bersalin pada usia kehamilan $>20$ minggu hingga $<$ 37 minggu (sampel kasus) dan ibu yang bersalin pada usia kehamilan $\geq 37$ minggu hingga $<42$ minggu (sampel kontrol). Sedangkan kriteria eksklusi yaitu pasien 
dengan catatan rekam medis tidak lengkap, sulit dimengerti oleh peneliti serta kehamilan pertama (sampel kasus dan kontrol) dan pasien yang terdiagnosa inkompetensi servik (sampel kasus).

Besar sampel ditentukan berdasarkan rumus hyphothesis test for the odds ratio dengan proporsi kejadian berdasarkan penelitian sebelumnya sehingga didapatkan sampel kasus sebanyak 137 orang dan sampel kontrol sebanyak 137 orang. Teknik sampel yang digunakan adalah simple random sampling pada kedua kelompok. Variabel bebas dalam penelitian ini adalah usia ibu bersalin, pendidikan ibu, pekerjaan ibu, dan riwayat persalinan preterm. Variabel terikat adalah persalinan preterm. Teknik pengumpulan data yang digunakan adalah teknik pengamatan/observasi berupa pengambilan data sekunder dari catatan rekam medis rumah sakit menggunakan lembar pengumpul data sebagai instrumen penelitian.

Berikut definisi operasional dari variabel penelitian.

Tabel 1 Definisi operasional variabel penelitian

\begin{tabular}{|c|c|c|c|c|}
\hline No & Variabel & Definisi Operasional & Alat Ukur & Kategori \\
\hline \multicolumn{5}{|c|}{ Variabel Terikat } \\
\hline 1. & $\begin{array}{l}\text { Persalinan } \\
\text { Preterm }\end{array}$ & $\begin{array}{l}\text { Persalinan yang berlangsung } \\
\text { pada umur kehamilan } 20-37 \\
\text { minggu dihitung dari hari } \\
\text { pertama haid terakhir. }\end{array}$ & $\begin{array}{l}\text { Lembar } \\
\text { Pengumpul } \\
\text { Data }\end{array}$ & $\begin{array}{l}\text { 0: Tidak Preterm } \\
\text { 1: Preterm }\end{array}$ \\
\hline \multicolumn{5}{|c|}{ Variabel Bebas } \\
\hline 2. & $\begin{array}{l}\text { Usia } \\
\text { bersalin }\end{array}$ & $\begin{array}{l}\text { Usia ibu pada } r \text { saat } \\
\text { melahirkan sesuai catatan } \\
\text { dalam rekam } \\
\text { medik }\end{array}$ & $\begin{array}{l}\text { Lembar } \\
\text { Pengumpul } \\
\text { Data }\end{array}$ & $\begin{array}{l}0: \text { tidak berisiko }(20-35 \\
\text { th }) \\
\text { 1: berisiko }(<20 \text { th dan }> \\
35 \text { th })\end{array}$ \\
\hline 3. & Pendidikan & $\begin{array}{l}\text { Pendidikan formal tertinggi } \\
\text { yang ditamatkan oleh ibu } \\
\text { sesuai dengan data rekam } \\
\text { medik }\end{array}$ & $\begin{array}{l}\text { Lembar } \\
\text { Pengumpul } \\
\text { Data }\end{array}$ & 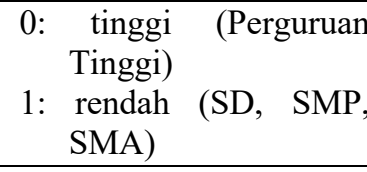 \\
\hline 4. & Pekerjaan & $\begin{array}{l}\text { Kegiatan rutin yang } \\
\text { dilakukan oleh ibu dalam } \\
\text { kehidupan sehari-hari dilihat } \\
\text { dalam catatan rekam medik }\end{array}$ & $\begin{array}{l}\text { Lembar } \\
\text { Pengumpul } \\
\text { Data }\end{array}$ & $\begin{array}{l}\text { 0:Tidak bekerja (IRT) } \\
\text { 1: bekerja (Pegawai dan } \\
\text { wiraswasta ) }\end{array}$ \\
\hline 5. & $\begin{array}{l}\text { Riwayat } \\
\text { Persalinan } \\
\text { Preterm }\end{array}$ & $\begin{array}{l}\text { Ibu yang mempunyai riwayat } \\
\text { persalinan prematur pada } \\
\text { kehamilan sebelumnya }\end{array}$ & $\begin{array}{l}\text { Lembar } \\
\text { Pengumpul } \\
\text { Data }\end{array}$ & $\begin{array}{l}\text { 0: Tidak ada riwayat } \\
\text { 1: Ada Riwayat }\end{array}$ \\
\hline
\end{tabular}

Sumber: Creasy et al., 2009 ; Krisnadi, Effendi dan Pribadi, 2009

Pengumpulan data dilakukan pada bulan Maret - April 2019 dimulai dengan penentuan sampel penelitian yang diambil dari catatan rekam medis rumah sakit di ruangan bersalin yaitu buku register bayi baru lahir dan buku operan harian. Pengolahan data dilakukan dengan editing, coding, data entry, dan cleaning. Data yang sudah terkumpul dan diolah kemudian dianalisis menggunakan analisis 
univariat dan analisis bivarat Chi-Square Test dengan bantuan program komputer SPSS 24 for windows.

\section{HASIL DAN PEMBAHASAN}

\section{Usia Ibu Bersalin}

Usia ibu bersalin dibagi menjadi usia berisiko yaitu usia kurang dari 20 tahun dan lebih dari 35 tahun serta usia tidak berisiko yaitu usia 20-35 tahun.

Tabel 2 Hubungan usia ibu dengan kejadian persalinan preterm di RSUD Dr. Soetomo Surabaya

\begin{tabular}{cccccccc}
\hline \multirow{2}{*}{$\begin{array}{l}\text { Usia Ibu } \\
\text { Bersalin }\end{array}$} & \multicolumn{3}{c}{ Persalinan Preterm } & \multicolumn{2}{c}{ Total } & \multirow{2}{*}{ Nilai p } \\
\cline { 2 - 6 } & Freterm & \multicolumn{2}{c}{ Tidak Preterm } & & \\
\hline Berisiko & 45 & 32,8 & 55 & 40,1 & 100 & 36,5 & \\
\hline Tidak Berisiko & 92 & 67,2 & 82 & 59,9 & 174 & 63,5 & 0,259 \\
\hline Total & $\mathbf{1 3 7}$ & $\mathbf{1 0 0}$ & $\mathbf{1 3 7}$ & $\mathbf{1 0 0}$ & $\mathbf{2 7 4}$ & $\mathbf{1 0 0}$ & \\
\hline
\end{tabular}

Pada tabel 2 dapat disimpulkan bahwa presentase kejadian persalinan preterm lebih tinggi pada subjek penelitian dengan usia ibu bersalin tidak berisiko pada rentang usia 20-35 tahun yaitu sebanyak 67,2\% dibandingkan subjek penelitian yang mempunyai usia berisiko yaitu 32,8\%. Hal ini juga terjadi pada kelompok kontrol yaitu tidak adanya kejadian persalinan preterm dengan prevalensi tertinggi pada subjek penelitian dengan usia ibu tidak berisiko yaitu 59,9\% dibandingkan subjek penelitian yang mengalami KPD yaitu $40,1 \%$.

Namun berdasarkan hasil analisis dengan uji Chi Square antara usia ibu bersalin dengan kejadian persalinan preterm diperoleh nilai signifikasi (p) adalah $0,259(\mathrm{p}>0,05)$. Nilai ini menyatakan bahwa tidak terdapat hubungan bermakna antara usia ibu bersalin dengan kejadian persalinan preterm.

\section{Pendidikan Ibu}

Variabel pendidikan ibu dibagi dalam dua kategori yaitu pendidikan rendah dan pendidikan tinggi. Pendidikan rendah yaitu ibu yang tamat pada jenjang pendidikan SD, SMP dan SMA. Sedangkan pendidikan tinggi adalah ibu yang tamat pada jenjang pendidikan perguruan tinggi yaitu setara diploma, sarjana, magister dan doktor.

Tabel 3 Hubungan pendidikan ibu dengan kejadian persalinan preterm di RSUD Dr. Soetomo Surabaya

\begin{tabular}{|c|c|c|c|c|}
\hline \multirow{2}{*}{$\begin{array}{l}\text { Pendidikan } \\
\text { Ibu Bersalin }\end{array}$} & \multicolumn{2}{|c|}{ Persalinan Preterm } & \multirow{2}{*}{ Total } & \multirow{2}{*}{ Nilai p } \\
\hline & Preterm & Tidak Preterm & & \\
\hline
\end{tabular}


Indonesian Midwifery and Health Sciences Journal

\begin{tabular}{ccccccc}
\hline & F & $\mathbf{\%}$ & $\mathbf{F}$ & $\mathbf{\%}$ & $\mathbf{F}$ & $\mathbf{\%}$ \\
\hline Rendah & 120 & 87,6 & 121 & 88,3 & 241 & 88,0 \\
\hline Tinggi & 17 & 12,4 & 16 & 11,7 & 33 & 12,0 \\
\hline Total & $\mathbf{1 3 7}$ & $\mathbf{1 0 0}$ & $\mathbf{1 3 7}$ & $\mathbf{1 0 0}$ & $\mathbf{2 7 4}$ & $\mathbf{1 0 0}$ \\
\hline
\end{tabular}

Pada tabel 3 dapat disimpulkan bahwa presentase pendidikan ibu terbesar yaitu pendidikan rendah sebesar $88 \%$ yang terbagi dalam kelompok kasus sebesar $87,6 \%$ dan kelompok kontrol sebesar 88,3\%. Hanya sebagian kecil presentase pendidikan tinggi pada ibu dengan persalinan preterm yaitu $12 \%$ dan $11,7 \%$ pada ibu yang tidak m engalami perasalinan preterm.

Namun berdasarkan hasil analisis dengan uji Chi Square antara pekerjaan ibu bersalin dengan kejadian persalinan preterm diperoleh nilai signifikasi (p) adalah 1 $(p>0,05)$. Nilai ini menyatakan bahwa tidak terdapat hubungan bermakna antara pekerjaan ibu bersalin dengan kejadian persalinan preterm.

\section{Pekerjaaan Ibu}

Variabel pekerjaan ibu dibagi dalam dua kategori yaitu bekerja seperti pegawai dan wiraswasta sedangkan tidak bekerja yaitu ibu rumah tangga.

Tabel 4 Hubungan pekerjaan ibu dengan kejadian persalinan preterm di RSUD Dr. Soetomo Surabaya

\begin{tabular}{cccccccc}
\hline \multirow{2}{*}{$\begin{array}{c}\text { Pekerjaan Ibu } \\
\text { Bersalin }\end{array}$} & \multicolumn{4}{c}{ Persalinan Preterm } & \multicolumn{2}{c}{ Total } & \multirow{2}{*}{ Nilai p } \\
\cline { 2 - 6 } & \multicolumn{3}{c}{ Preterm } & \multicolumn{2}{c}{ Tidak Preterm } & & \\
\hline Bekerja & 67 & 48,9 & 57 & 41,6 & 124 & 45,3 & \\
\hline Tidak Bekerja & 70 & 51,1 & 80 & 58,4 & 150 & 54,7 & \multirow{2}{*}{0,225} \\
\hline Total & $\mathbf{1 3 7}$ & $\mathbf{1 0 0}$ & $\mathbf{1 3 7}$ & $\mathbf{1 0 0}$ & $\mathbf{2 7 4}$ & $\mathbf{1 0 0}$ & \\
\hline
\end{tabular}

Pada tabel 4 dapat disimpulkan bahwa presentase ibu yang bekerja dan tidak bekerja tidak terlalu jauh berbeda yaitu $45,3 \%$ pada ibu bekerja dan $54,7 \%$ pada ibu tidak bekerja. Namun pada kedua kelompok, presentase terbesar ada pada ibu tidak bekerja yaitu sebesar 51,1\% pada kelompok kasus dan 58,4\% pada kelompok kontrol.

Berdasarkan hasil analisis dengan uji Chi Square antara pekerjaanibu bersalin dengan kejadian persalinan preterm diperoleh nilai signifikasi (p) adalah 0,225 (p $>0,05)$. Nilai ini menyatakan bahwa tidak terdapat hubungan bermakna antara pekerjaan ibu bersalin dengan kejadian persalinan preterm.

\section{Riwayat Persalinan Preterm}


Tabel 5 Hubungan riwayat persalinan preterm ibu dengan kejadian persalinan preterm di RSUD Dr. Soetomo Surabaya

\begin{tabular}{|c|c|c|c|c|c|c|c|}
\hline \multirow{3}{*}{$\begin{array}{c}\text { Riwayat } \\
\text { Persalinan } \\
\text { Preterm }\end{array}$} & \multicolumn{4}{|c|}{ Persalinan Preterm } & \multirow{2}{*}{\multicolumn{2}{|c|}{ Total }} & \multirow{3}{*}{ Nilai $p$} \\
\hline & \multicolumn{2}{|c|}{ Preterm } & \multicolumn{2}{|c|}{ Tidak Preterm } & & & \\
\hline & $\mathbf{F}$ & $\%$ & $\mathbf{F}$ & $\%$ & $\mathbf{F}$ & $\%$ & \\
\hline Ada Riwayat & 15 & 10,9 & 8 & 5,8 & 23 & 8,4 & \multirow{3}{*}{0,191} \\
\hline Tidak Ada Riwayat & 122 & 89,1 & 129 & 94,2 & 251 & 91,6 & \\
\hline Total & 137 & 100 & 137 & 100 & 274 & 100 & \\
\hline
\end{tabular}

Pada tabel 5 dapat disimpulkan bahwa sebagian besar ibu yang mengalami persalinan preterm yaitu $89,1 \%$ sebelumnya tidak memiliki riwayat persalinan preterm. Hal ini juga terjadi pada ibu yang tidak mengalami persalinan preterm yaitu $94,2 \%$ sebelumnya tidak memiliki riwayat persalinan preterm.

Berdasarkan hasil analisis dengan uji Chi-Square antara riwayat persalinan preterm dengan kejadian persalinan preterm diperoleh nilai signifikasi (p) adalah $0,191(\mathrm{p}>\alpha)$. Nilai ini menandakan bahwa $\mathrm{H}_{0}$ diterima yang berarti tidak terdapat hubungan bermakna antara riwayat persalinan preterm dengan kejadian persalinan preterm.

Hasil penelitian untuk variabel riwayat persalinan preterm didapatkan presentase lebih tinggi yaitu 55 subjek penelitian $(40,1 \%)$ pada ibu usia risiko yang mengalami persalinan tidak preterm dibandingkan ibu bersalin preterm yaitu 45 subjek penelitian (32,8\%). Hal ini tidak sejalan dengan penelitian Mutmainah dan Rositawati (2015) bahwa proporsi responden ibu bersalin dengan usia risiko pada kelompok kasus lebih tinggi $(72,1 \%)$ daripada kelompok kontrol $(50,8 \%)$ padahal menurut teori Soewarto (2010) usia terbaik untuk melahirkan adalah usia 20-35 tahun atau usia reproduksi.

Pada hasil penelitian bivariat didapatkan bahwa sebanyak $46(32,8 \%)$ usia ibu berisiko mengalami persalinan preterm dan 92 (67,2\%) usia ibu tidak berisiko mengalami persalinan preterm. Hasil uji Chi Square antara usia ibu dengan kejadian persalinan preterm menunjukkan bahwa tidak terdapat hubungan signifikan antara usia ibu dengan kejadian persalinan preterm. Hasil ini sejalan dengan penelitian Niswah (2016) bahwa usia ibu tidak memiliki hubungan dengan kejadian persalinan preterm. Namun hasil ini tidak sejalan dengan penelitian Carolin dan Widiastuti (2019) yang menunjukkan bahwa adanya hubungan bermakna antara usia ibu dengan persalinan preterm dan menyatakan bahwa persalinan preterm yang terjadi pada usia risiko seperti usia kurang dari 20 tahun dapat disebabkan karena panggul 
dan rahim yang masih kecil serta alat reproduksi yang belum matang dan pada usia diatas 35 tahun dapat disebabkan karena penurunan kematangan organ reproduksi sehingga usia risiko dapat menimbulkan masalah kesehatan pada saat persalinan dan berisiko terjadi persalinan preterm.

Hal ini sesuai dengan teori bahwa mekanisme biologis terjadinya persalinan preterm pada kehamilan usia dini, yaitu kehamilan yang terjadi di usia remaja di bawah 20 tahun, dikarenakan belum sempurnanya peredaran darah menuju serviks dan uterus yang kemudian dapat menyebabkan kurangnya peredaran darah ke saluran genital dan juga dapat meningkatkan kejadian infeksi sehingga dapat mengakibatkan persalinan preterm (Krisnadi et al, 2009). Sedangkan penelitian Mutmainah dan Rositawati (2015) menerangkan bahwa usia diatas 35 tahun merupakan usia yang berisiko yaitu mulai terlihat pengaruh proses penuaan dengan munculnya penyakit seperti hipertensi dan diabetes melitus yang dapat menghambat sirkulasi nutrisi dari ibu ke janin melalui plasenta sehingga hal ini dapat menyebabkan terjadinya persalinan preterm.

Menurut asumsi penulis bahwa penyebab kejadian persalinan preterm pada ibu usia reproduksi sendiri juga dipengaruhi oleh berbagai faktor lain diantaranya faktor idiopatik yang apabila penyebab persalinan premtur tidak diketahui, faktor iatrogenik yang apabila kelangsungan kehamilan dapat membahayakan ibu dan janin sehingga menyebabkan persalinan preterm, faktor sosio-demografik seperti kecemasan, stres, perilaku, dan kondisi sosioekonomi, faktor maternal seperti inkompetensi servik, kelainan uterus dan riwayat reproduksi, faktor genetik dan infeksi.

Hasil penelitian untuk variabel pendidikan ibu didapatkan presentase yang tidak jauh berbeda pada tingkat pendidikan rendah antara kelompok kasus $(87,6 \%)$ dan kelompok kontrol (88,3\%). Hal ini sejalan dengan penelitian Simbolon, Sori Muda dan Rasmaliah (2015) di RSUD Dr. Pirngadi Medan bahwa presentase pendidikan rendah pada kelompok kasus (24\%) lebih kecil dibandingkan kelompok kontrol (30\%) namun tidak jauh berbeda.

Pada hasil penelitian bivariat didapatkan bahwa sebanyak $120(87,6 \%)$ pendidikan rendah mengalami persalinan preterm dan $17(12,4 \%)$ pendidikan tinggi mengalami persalinan preterm. Hasil uji Chi Square menunjukkan bahwa tidak 
terdapat hubungan signifikan antara pendidikan ibu dengan kejadian persalinan preterm.

Hasil ini sejalan dengan penelitian Simbolon, Sori Muda dan Rasmaliah (2015) bahwa tingkat pendidikan ibu tidak memiliki pengaruh yang bermakna dengan kejadian persalinan preterm. Namun Ondang, Suparman dan Tendean (2016) dalam penelitiannya menyatakan bahwa pendidikan ibu berkaitan erat dengan pengetahuan dan pentingnya pemeliharaan kandungan semasa kehamilan, dimana pendidikan ibu yang rendah dapat menyulitkan berlangsungnya penyuluhan kesehatan terhadap ibu hamil sehingga mereka tidak melakukan pemeliharaan kesehatan yang baik saat kehamilan dan menurut asumsi penulis bahwa hal inilah yang dapat menyebabkan insiden persalinan prematur lebih tinggi pada ibu yang mempunyai pendidikan rendah.

Hasil penelitian untuk variabel pekerjaan ibu didapatkan presentase lebih tinggi yaitu 65 subjek penelitian $(48,9 \%)$ pada ibu bekerja yang mengalami persalinan preterm dibandingkan ibu yang tidak bekerja yaitu 55 subjek penelitian (41,6\%). Hal ini sejalan dengan penelitian Mutmainah dan Rositawati (2015) bahwa presentase ibu yang bekerja pada kelompok kasus lebih tinggi yaitu 78,7\% daripada kelompok komtrol yaitu 55,7\% dan penelitian Rerung (2014) bahwa terdapat $70 \%$ ibu yang memiliki pererjaan berisiko atau ibu yang bekerja dibandingkan ibu yang kurang berisiko atau ibu yang tidak bekerja yaitu sebesar $40 \%$.

Pada hasil penelitian bivariat didapatkan bahwa sebanyak 67 (48,9\%) ibu yang bekerja mengalami persalinan preterm dan lebih banyak pada ibu yang tidak bekerja yaitu $70(51,1 \%)$ yang mengalami persalinan preterm. Namun hasil uji Chi Square menyatakan bahwa tidak terdapat hubungan signifikan antara pekerjaan ibu dengan kejadian persalinan preterm.

Hal ini berbeda dengan teori Krisnadi, Effendi dan Pribadi (2009) yang menyatakan bahwa pekerjaan ibu dapat meningkatkan kejadian persalinan preterm melalui kelelahan fisik atau stres yang timbul akibat pekerjaannya dan terbukti bahwa kejadian persalinan preterm meningkat 1,3 kali lebih tinggi bila ibu hamil bekerja lebih dari 42 jam per minggu, bila berdiri lebih dari 6 jam sehari, dan bila tingkat kepuasan kerjanya rendah. Penelitian Mutmainah dan Rita (2015) juga 
menyatakan bahwa terdapat hubungan bermakna antara pekerjaan ibu dengan kejadian persalinan prematur dan pekerjaan ibu berisiko mengakibatkan persalinan preterm 2,9 kali lipat lebih besar daripada ibu yang tidak bekerja. Serupa dengan penelitian Rerung (2014) bahwa ibu bekerja memiliki risiko 3,5 kali lipat lebih besar mengalami kejadian persalinan preterm dibandingkan ibu yang kurang melakukan aktivitas diluar rumah.

Mutmainah dan Rita (2015) menerangkan bahwa peningkatan persalinan preterm pada ibu bekerja dikarenakan pekerjaan seperti mengangkat beban berat dapat meningkatkan tekanan intra abdomen sehingga akan memicu peningkatan kontraksi uterus dan menyebabkan persalinan preterm. Tidak ada hubungan yang bermakna pada penelitian ini didukung oleh pernyataan Ondang, Suparman dan Tendean (2016) yang mengatakan bahwa salah satu pemicu persalinan prematur pada ibu yang tidak bekerja dapat disebabkan oleh stres yang dialami ibu dikarenakan banyaknya pekerjaan rumah tangga yang dilakukan selama kehamilan.

Hasil penelitian untuk variabel riwayat persalinan preterm didapatkan presentase lebih tinggi yaitu 15 subjek penelitian (10,9\%) pada ibu dengan riwayat persalinan preterm yang mengalami persalinan preterm dibandingkan ibu bersalin tidak preterm yaitu 8 subjek penelitian $(5,8 \%)$. Hal ini sejalan dengan penelitian Ariana, Sayono dan Kusumawati (2012) di BPM Wilayah Kerja Puskesmas Geyer dan Puskesmas Toroh bahwa proporsi responden ibu bersalin multiparitas yang memiliki riwayat persalinan preterm pada kelompok kasus lebih tinggi $(61,5 \%)$ daripada kelompok kontrol (34,6\%).

Setelah dilakukan uji Chi Square dapat disimpulkan bahwa tidak terdapat hubungan bermakna antara riwayat persalinan preterm sebelumnya dengan kejadian persalinan preterm. Hasil ini sejalan dengan penelitian Ariana, Sayono dan Kusumawati (2012) bahwa riwayat persalinan preterm tidak memiliki hubungan dengan persalinan preterm tetapi merupakan faktor risiko terhadap terjadinya persalinan preterm dengan peluang 3,022 kali lipat lebih besar pada ibu dengan riwayat persalinan preterm daripada tidak memiliki riwayat.

Namun hasil penelitian ini tidak sejalan dengan penelitian yang dilakukan oleh Anasari dan Pantiawati (2016) yang menyatakan bahwa terdapat hubungan antara riwayat persalinan preterm dengan kejadian persalinan preterm dan berpeluang 
3,206 kali lipat lebih tinggi untuk megalami perslainan preterm pada ibu yang sebelumnya mempunyai riwayat persalinan preterm. Begitu pula dengan penelitian Paembonan, Ansar dan Arsyad (2014) menyatakan bahwa riwayat persalinan preterm merupakan faktor risiko kejadian persalinan preterm sebesar 20,054 kali lipat.

Menurut teori riwayat persalinan prematur sebelumnya merupakan faktor risiko utama untuk kelahiran prematur pada kehamilan selanjutnya. Dalam teori lainnya dijelaskan bahwa persalinan preterm berpeluang untuk terulang kembali pada persalinan selanjutnya dan diwariskan secara genetik pada ekspresi sitokin melalui jalur inflamasi yang krmudian akan menstimulasi pembentukkan prostaglandin dan metaloproteinase (MMP) untuk memicu kontraksi uterus dan pematangan serviks sehingga dapat mengakibatkan persalinan preterm (Pandey, Chauhan dan Awasthi, 2018)

Penelitian di dalam buku Fadlun dan Feryanto (2011) yang dilakukan di Scotlandia menunjukkan bahwa riwayat persalinan preterm sebelumnya akan meningkatkan risiko persalinan preterm selanjutnya 3 kali lipat lebih besar dan besar risiko ini juga didapatkan pada penelitian di RSUD Prof. Dr. Margono Soekarjo Purwokerto sebesar 3,2 kali lipat lebih besar untuk mengalami persalinan preterm (Anasari dan Pantiawati, 2016).

Perbedaan hasil penelitian ini dengan penelitian Anasari dan Pantiawati (2016) dipengaruhi oleh besar sampel dan karena terbatasnya sampel yang mempunyai riwayat persalinan preterm sebelumnya (proporsi sebesar 10,9\%) pada kelompok kasus. Selain itu subjek penelitian pada penelitian ini yang memiliki riwayat persalinan preterm belum diketahui penyebabnya secara pasti. Sesuai dengan teori yang menyatakan bahwa telah banyak ditemukannya masalah medis ibu dan komplikasi persalinan seperti preeklampsia berat (PEB), perdarahan antepartum, diabetes melitus, atau penyakit jantung berat yang menyebabkan persalinan prematur elektif (Creasy et al., 2009) pada kehamilan sekarang maupun kehamilan sebelumnya. 
Dapat disimpulkan bahwa faktor risiko seperti usia ibu bersalin, pendidikan ibu, pekerjaan ibu dan riwayat persalinan preterm ibu tidak memiliki hubungan dengan kejadian persalinan preterm.

Ibu bersalin dan keluarga diharapkan untuk meningkatkan kesadaran akan pentingnya kunjungan ANC (Antenatal Care) secara dini dan teratur dalam mengidentifikasi faktor risiko lebih awal sehingga dapat dilakukan perencanaan dan perawatan untuk mencegah dampak buruk dan ibu dapat membawa kehamilannya hingga aterm. Bagi tempat penelitian untuk memberikan pendidikan kesehatan berupa materi preventif dan promotif mengenai persalinan preterm. Peneliti selanjunya disarankan untuk melakukan penelitian lebih lanjut mengenai faktor risiko lainn yang dapat mempengaruhi persalnan preterm.

\section{DAFTAR PUSTAKA}

Anasari, T. dan Pantiawati, I. (2016) "Faktor-Faktor Yang Mempengaruhi Persalinan Preterm Di RSUD Prof. Dr. Margono Soekarjo Purwokerto," Jurnal Kebidanan, 8(01), hal. 94-109.

Ariana, D. N., Sayono dan Kusumawati, E. (2012) "Faktor Risiko Kejadian Persalinan Prematur (Studi di Bidan Praktek Mandiri Wilayah Kerja Puskesmas Geyer dan Puskesmas Toroh Tahun 2011)," Jurnal Kebidanan Universitas Muhammadiyah Semarang, 1(1), hal. 1-13. doi: 10.26714/jk.1.1.2012.33-40.

Blencowe, H. et al. (2012) "15 Million Preterm Births: Priorities for Action Based on National, Regional and Global Estimates," in Born Too Soon - The Global Action Report on Preterm Birth, hal. 17-31. Tersedia pada: http://www.who.int/pmnch/media/news/2012/borntoosoon_chapter2.pdf.

Carolin, B. T. dan Widiastuti, I. (2019) "Faktor-Faktor Yang Berhubungan Dengan Kejadian Persalinan Preterm Di Rumah Sakit Muhammadiyah Tama Puring Kebayoran Baru Jakarta Selatan Periode Januari - Juni Tahun 2017," Jurnal Ilmu Keperawatan Dan Kebidanan Nasional, 1(1).

Creasy, R. K. et al. (2009) Creasy and Resnik's Maternal-fetal Medicine: Principles and Practice. Sixth Edit. Diedit oleh R. K. Creasy et al. Saunders/Elsevier (Expert Consult Series). Tersedia pada: https://books.google.co.id/books?id=y4tntQAACAAJ.

Djajakusli, S., Harianto, A. dan Etika, R. (2017) "Profil Kematian Neonatus di RSUD dr. Soetomo," Jurnal Ilmu Kesehtan Anak, 18(6).

Fadlun dan Feryanto, A. (2011) Asuhan Kebidanan Patologis. Jakarta: Salemba Medika.

Krisnadi, S. R., Effendi, J. S. dan Pribadi, A. (ed.) (2009) Prematuritas. Bandung: PT Refika Aditama.

Lissauer, T. dan Farnaroff, A. A. (2013) Selayang Neonatologi Edisi Kedu. Jakarta: Indeks.

Mochtar, A. B. (2010) Ilmu Kebidanan Sarwono Prawirohardjo. Keempat. Diedit 
oleh A. B. Saifuddin, T. Rachmhadhi, dan G. H. Winkhjosastro. Jakarta: PT Bina Pustaka Sarwono Parwirohardjo.

Mutmainah dan Rositawati, R. (2015) "Faktor - Faktor Yang Berhubungan Dengan Kejadian Persalinan Prematur Di RSUD dr . Adjidarmo Rangkasbitung Tahun 2013," Jurnal Obstretika Scienta, 3(2). Tersedia pada: https://ejurnal.latansamashiro.ac.id/index.php/OBS/article/view/175.

Niswah, F. I. (2016) Faktor Risiko Kejadian Persalinan Prematur (Studi Kasus di RSUD Tugurejo Semarang). Universitas Negeri Semarang.

Ondang, M. C., Suparman, E. dan Tendean, H. M. M. (2016) "Gambaran Persalinan Prematur Pada Kehamilan Remaja di RSUP Prof. Dr. R. D. Kandou Manado periode 1 Januari - 31 Desember 2015," Jurnal e-Clinic, 4(2). Tersedia pada: https://ejournal.unsrat.ac.id/index.php/eclinic/article/view/14487.

Paembonan, N., Ansar, J. dan Arsyad, D. S. (2014) "Faktor Risiko Kejadian Kelahiran Prematur Di Rumah Sakit Ibu dan Anak Siti Fatimah Kota Makassar," Jurnal Universitas Hasanudin.

Pandey, M., Chauhan, M. dan Awasthi, S. (2018) "Interplay of cytokines in preterm birth," The Indian Journal of Medical Research, (January), hal. 1-12. doi: 10.4103/ijmr.IJMR.

Rerung, N. M. (2014) "Faktor Risiko Kejadian Persalinan Prematur Di Rumah Sakit Daya Makassar Tahun 2011," Jurnal STIKES Nani Hasanuddin Makassar, 4, hal. 90-97.

Simbolon, F., Sori Muda, S. dan Rasmaliah (2015) "Faktor Risiko Kejadian Persalinan Prematur Di RSUD DR. Pringadi Kota Medan Tahun 2010-2013," Jurnal Gizi, Kesehatan Reproduksi dan Epidemiologi FKM USU, 1(1).

Soewarto, S. (2010) Ilmu Kebidanan Sarwono Prawirohardjo. Keempat. Diedit oleh A. B. Saifuddin, T. Rachmhadhi, dan G. H. Winkhjosastro. Jakarta: PT Bina Pustaka Sarwono Parwirohardjo.

Syarif, A. B., Santoso, S. dan Widyasih, H. (2017) "Usia Ibu dan Kejadian Persalinan Preterm," Kesehatan Ibu dan Anak, 11(2), hal. 20-24. 